\title{
Perilaku orang tua dalam pemberian makan dan status gizi anak usia 2-5 tahun
}

Parents' behavior in feeding children and nutrition status of children aged 2-5 years

Ni Luh Agustini Purnama ${ }^{1}$, Lely Lusmilasari ${ }^{2}$, Madarina Julia ${ }^{3}$

\begin{abstract}
Background: The issue of child nutrition is still a problem in developing countries, including Indonesia. Nowdays, there are double burden related to child nutrition, due to lack of nutrition that has not been resolved and at the same time there is increasing problem of excess nutrients. Parents are responsible for the care of children, including fulfilling a balanced nutritional intake. Objective: To identify the relationship between parent's behavior in feeding and nutritional status of children aged 2-5 years. Method: Design used in this study was observational with cross sectional study was conducted 153 parents with children aged 2-5 years who fit the inclusion and exclusion criteria in the region of Integrated Health Center Catholic Hospital St. Vincentius a Paulo Surabaya. Parent's behavior in feeding was assessed using the Comprehensive Feeding Practices Questionnaire (CFPQ) which consists of 49 questions and 12 behavioral aspects. The nutritional status of children assessed by weight indicator according to height (weight/height) were compared with z-score WHO 2006 standard. Data were analyzed using the Spearman correlation. Results: The average nutritional status of children aged 2-5 years based on the weight/height $z$-score indicator was 0.17 indicating that is in normal condition. Parent's behavior that involve children in the planning and preparation of meals, positively associated with nutritional status of children in all conditions of nutritional status of children who are very thin to obese $(\rho=0.43 ; p=0.001)$. Pressure when children eat was negatively associated with nutritional status of children aged 2-5 years in normal nutritional status to obese $(\rho=-0.34 ; p=0.001)$. Restriction of food intake to control body weight was positively associated with nutritional status of children aged 2-5 years in all conditions of nutritional status of children who are very thin to obese $(\rho=0.29 ; p=0.001)$. Conclusion: Parent's behavior in feeding the children associated with nutritional status of children aged 2-5 years.
\end{abstract}

KEY WORDS: nutritional status, feeding behavior, age 2-5 years

\begin{abstract}
ABSTRAK
Latar belakang: Permasalahan tentang gizi anak masih menjadi masalah di negara-negara berkembang termasuk Indonesia. Saat ini terjadi permasalahan ganda terkait gizi anak karena masalah gizi kurang yang belum teratasi dan pada saat yang sama masalah kelebihan gizi makin meningkat. Orang tua bertanggung jawab dalam pengasuhan anak termasuk memenuhi asupan gizi yang seimbang. Perilaku orang tua dalam pemberian makan pada anak merupakan faktor yang sangat penting dalam mempengaruhi asupan nutrisi anak. Tujuan: Mengidentifikasi hubungan antara perilaku orang tua dalam pemberian makan dan status gizi anak usia 2-5 tahun. Metode: Desain penelitian observasional dengan rancangan cross sectional. Subjek penelitian 153 orang tua dengan anak usia 2-5 tahun yang sesuai kriteria inkusi dan ekslusi di wilayah posyandu binaan Rumah Sakit Katolik St. Vincentius a Paulo Surabaya. Perilaku orang tua dalam pemberian makan dinilai menggunakan comprehensive feeding practices questionnaire (CFPQ). Status gizi anak dinilai berdasarkan indikator berat badan menurut tinggi badan (BB/TB) yang dibandingkan dengan standar z-skor WHO 2006. Data dianalisis dengan menggunakan korelasi Spearman. Hasil: Rerata status gizi anak usia 2-5 tahun berdasarkan z-skor $\mathrm{BB} / \mathrm{TB}=0,17$ yang menunjukkan kondisi normal. Orang tua yang melibatkan anak dalam perencanaan dan persiapan makan berhubungan positif dengan status gizi anak pada anak yang sangat kurus hingga gemuk $(\rho=0,43 ; p=0,001)$. Orang tua yang memberikan tekanan saat anak makan berhubungan negatif dengan status gizi pada anak yang sangat kurus hingga gemuk $(\rho=-0,34 p=0,001)$. Pembatasan asupan makanan untuk mengontrol berat badan berhubungan signifikan secara positif dengan status gizi anak yang sangat kurus sampai gemuk $(\rho=0,29 ; p=0,001)$. Simpulan: Ada hubungan antara perilaku orang tua dalam pemberian makan pada anak dengan status gizi anak usia 2-5 tahun.
\end{abstract}

KATA KUNCI: status gizi, perilaku pemberian makan, usia 2-5 tahun

\footnotetext{
Korespondensi: STIKES Katolik St. Vincentius a Paulo Surabaya, J1. Jambi 12-18, Surabaya, Jawa Timur 60241, e-mail: niluh_stikvinct@yahoo.com

2 Program Studi Ilmu Keperawatan Fakultas Kedokteran Universitas Gadjah Mada Yogyakarta, e-mail: lely lusmilasari@yahoo.com

3 Bagian Ilmu Kesehatan Anak Rumah Sakit Umum Pusat Dr. Sardjito/Fakultas Kedokteran Universitas Gadjah Mada Yogyakarta, e-mail: madarinajulia@yahoo.com
} 


\section{PENDAHULUAN}

Asupan nutrisi yang cukup merupakan kebutuhan dasar yang diperlukan anak dalam siklus kehidupannya untuk perkembangan dan menjaga fungsi tubuh (1). Permasalahan tentang gizi anak masih menjadi masalah di negara-negara berkembang termasuk Indonesia (2). Masalah gizi cenderung bertambah berat dengan terjadinya masalah ganda karena kekurangan gizi belum teratasi, tetapi masalah kelebihan gizi semakin meningkat (3). Berdasarkan data Riskesdas 2013, prevalensi balita kurus dan sangat kurus di Indonesia sebesar 12,1\% dan prevalensi gemuk sebesar 11,9\% (4). Masalah gizi pada anak memerlukan perhatian khusus karena dapat menyebabkan peningkatan kesakitan, kematian, mempengaruhi kecerdasan serta hambatan pertumbuhan dan perkembangan $(2,5)$.

Perilaku pemberian makan yang dilakukan orang tua berperan penting dalam memenuhi kebutuhan nutrisi anak $(6,7)$. Orang tua bertanggung jawab terhadap pengasuhan anak termasuk memenuhi kebutuhan nutrisi bagi pertumbuhan dan perkembangan anak (8). Beberapa penelitian menunjukkan terkait masalah perilaku orang tua dalam pemberian makan pada anak misalnya menggunakan makanan manis sebagai hadiah untuk mengontrol anak dan tidak ada kontrol dalam pemilihan makanan anak (9). Orang tua tidak menentukan makanan yang sebaiknya dimakan anak, tetapi cenderung menuruti keinginan anak (10) dan memaksa anak untuk tetap makan meskipun anak sudah tidak mau (11).

Penelitian yang berkaitan dengan status gizi anak pernah dilakukan terutama dihubungkan dengan faktor sosial ekonomi, sanitasi lingkungan, infeksi, pekerjaan ibu, dan pengetahuan ibu tentang gizi (12-14), tetapi penelitian tentang status gizi yang dihubungkan dengan perilaku orang tua dalam pemberian makan pada anak usia 2-5 tahun masih terbatas terutama yang dilakukan di Indonesia. Tujuan penelitian ini adalah mengidentifikasi hubungan antara perilaku orang tua dalam pemberian makan dan status gizi anak usia 2-5 tahun.

\section{BAHAN DAN METODE}

Desain penelitian adalah observasi dengan rancangan penelitian cross sectional. Penelitian dilaksanakan pada bulan Agustus sampai September 2014 di posyandu binaan Rumah Sakit Katolik St. Vincentius a Paulo Surabaya yang terdiri dari empat posyandu. Posyandu Mawar II dan Posyandu Flamboyan II terletak pada Kecamatan Keputih, Kota Surabaya yang merupakan wilayah kerja Puskesmas Keputih. Posyandu Sedap Malam dan Posyandu Anyelir I terletak di Kelurahan Sawunggaling, Kecamatan Wonokromo, Kota Surabaya dan berada di bawah wilayah kerja Puskesmas Jagir.

Subjek penelitian adalah orang tua dan anak usia 2-5 tahun yang terdaftar di posyandu dan memenuhi kriteria inklusi maupun eksklusi. Kriteria inklusi orang tua (ayah atau ibu) yaitu mempunyai anak usia 2 sampai 5 tahun dan yang lebih dominan dalam melakukan pemberian makan pada anak; anak dalam keadaan sehat dan tidak menderita penyakit kronis, akut maupun infeksi misalnya diare; anak yang diasuh oleh orang tua dan tinggal serumah dengan orang tua. Kriteria eksklusi penelitian terdiri dari anak yang memiliki cacat bawaan seperti penyakit jantung, bibir sumbing, atresia ani, megakolon; orang tua dengan gangguan fisik atau mental seperti lumpuh atau keadaan lain yang menghambat orang tua dalam pemberian makan kepada anak. Pada penelitian ini teknik pengambilan sampel menggunakan sampling jenuh yaitu seluruh anggota populasi yang memenuhi kriteria inklusi maupun eksklusi menjadi subjek penelitian yaitu sebanyak 153 responden.

Penelitian ini dilaksanakan setelah mendapatkan ethical clearance dari Komisi Etik Penelitian Kedokteran dan Kesehatan Fakultas Kedokteran Universitas Gadjah Mada Yogyakarta dan mendapatkan informed consent yang sudah ditandatangai oleh orang tua. Setelah mendapat persetujuan dari orang tua, anak diukur berat badan dengan menggunakan timbangan digital dan pengukuran tinggi badan dengan menggunakan stadiometer. Orang tua diberikan kuesioner untuk mendapatkan data tentang identitas anak, orang tua, dan perilaku orang tua dalam pemberian makan pada anak.

Perilaku orang tua dalam pemberian makan pada anak dinilai dengan menggunakan comprehensive feeding practices questionnaire (CFPQ) yang dikembangkan oleh Musher-Eizenman (15). Pada penelitian ini 
kuesioner yang digunakan yaitu 49 item terdiri dari 12 aspek untuk menilai praktik orang tua yang berkaitan dengan pemberian makan pada anak. Aspek perilaku orang tua dalam pemberian makan pada anak antara lain mengontrol perilaku makan anak (5 item), menggunakan makanan untuk mengatur emosi anak (3 item), mendorong asupan makanan seimbang dan bervariasi (4 item), menyediakan lingkungan dengan makanan sehat di rumah (4 item), menggunakan makanan sebagai hadiah (3 item), melibatkan anak dalam perencanaan dan persiapan makan (3 item), memantau asupan makanan (4 item), memberikan contoh makan yang sehat (4 item), memberikan tekanan saat makan (4 item), pembatasan asupan makanan untuk kesehatan (4 item), pembatasan asupan makanan untuk mengontrol berat badan $(8$ item), dan pengajaran tentang gizi (3 item). Setiap butir pertanyaan memiliki 5 pilihan jawaban yaitu tidak pernah (skor 1), jarang (skor 2), kadang-kadang (skor 3), sering (skor 4), dan selalu (skor 5). Skor pada masing-masing aspek perilaku dihitung berdasarkan rerata dari masingmasing aspek perilaku orang tua dalam pemberian makan pada anak. Semakin tinggi skor menunjukkan semakin tinggi perilaku orang tua dalam pemberian makan pada anak pada masing-masing aspek (16). Hasil uji coba 49 pertanyaan dari kuesioner menunjukkan nilai yang valid ( $\mathrm{r}=0,560-0,782)$ dan reliabel dengan Alpha koefisien Cronbach $(\alpha)$ 0,893 pada semua item pertanyaan.

Status gizi anak dinilai dengan menggunakan software WHO anthro untuk menghitung z-skor berat badan terhadap tinggi badan. Korelasi Spearman dilakukan untuk mengetahui hubungan antara perilaku orang tua dalam pemberian makan dengan status gizi anak usia 2-5 tahun. Pengolahan dan analisis data menggunakan program komputer dengan tingkat kemaknaan $\mathrm{p}<0,05$ dan interval kepercayaan 95\%.

\section{HASIL}

Dari total 153 anak, ada 3 anak yang tidak memiliki ayah karena ayah telah meninggal dunia. Sebagian besar $(43,14 \%)$ pendapatan keluarga kurang dari $\mathrm{Rp}$ 2.200.000, nilai cut off pendapatan keluarga berdasarkan upah minimum Kota Surabaya sebesar Rp 2.200.000 (17). Rerata status gizi anak usia 2-5 tahun berdasarkan
Tabel 1. Karakteristik subjek

\begin{tabular}{|c|c|c|}
\hline Variabel & $\begin{array}{l}\text { Frekuensi } \\
\text { n (\%) }\end{array}$ & Mean \pm SD \\
\hline \multicolumn{3}{|l|}{ Karakteristik orang tua } \\
\hline Umur ayah (tahun) & 149 & $34,66 \pm 6,30$ \\
\hline Umur ibu (tahun) & 153 & $31,26 \pm 5,60$ \\
\hline $\begin{array}{l}\text { Tingkat pendidikan ibu } \\
\text { Pendidikan dasar } \\
\text { Pendidikan menengah } \\
\text { Pendidikan tinggi }\end{array}$ & $\begin{array}{l}43(28,10) \\
85(55,60) \\
25(16,30)\end{array}$ & \\
\hline \multicolumn{3}{|l|}{ Karakteristik keluarga } \\
\hline $\begin{array}{l}\text { Pendapatan keluarga } \\
\text { Kurang (<UMK) } \\
\text { Rata-rata (Rata-rata UMK) } \\
\text { Lebih (>UMK) }\end{array}$ & $\begin{array}{l}66(43,14) \\
47(30,72) \\
40(26,14)\end{array}$ & \\
\hline Jumlah anggota keluarga & & $3,90 \pm 1,06$ \\
\hline Jumlah balita dalam keluarga & & $1,24 \pm 0,48$ \\
\hline \multicolumn{3}{|l|}{ Karakteristik anak } \\
\hline \multicolumn{3}{|l|}{ Umur (bulan) } \\
\hline $24-36$ & $65(42,50)$ & \\
\hline $37-60$ & $88(57,50)$ & \\
\hline Tinggi badan $(\mathrm{cm})$ & & $94,28 \pm 8,63$ \\
\hline $\begin{array}{l}\text { Status gizi berdasarkan } \mathrm{BB} / \mathrm{TB} \\
\text { (skor-Z) }\end{array}$ & & $0,18 \pm 1,54$ \\
\hline \multicolumn{3}{|l|}{ Kategori status gizi (BB/TB) } \\
\hline Sangat kurus & $1(0,70)$ & \\
\hline Kurus & $5(3,30)$ & \\
\hline Normal & $129(84,30)$ & \\
\hline Gemuk & $18(11,70)$ & \\
\hline
\end{tabular}

$\mathrm{UMK}=$ Upah Minimum Kabupaten/Kota Surabaya (Rp 2.200.000); $\mathrm{BB} / \mathrm{TB}=$ berat badan/tinggi badan

indikator z-skor BB/TB adalah 0,18. Hal ini menunjukkan bahwa rerata status gizi anak usia 2-5 tahun berada pada kondisi normal yaitu pada rentang z-skor -2 sampai dengan 2 SD (Tabel 1).

Tabel 2 menunjukkan bahwa dari total 153 subjek penelitian, perilaku pemberian makan yang paling sering dilakukan orang tua adalah menyediakan lingkungan dengan makanan sehat di rumah dan memberikan contoh makan yang sehat. Skor rata-rata yang terendah dari perilaku orang tua dalam pemberian makan adalah pembatasan asupan makanan untuk mengontrol berat badan yaitu sebesar 1,9 artinya pada rentang tidak pernah sampai jarang.

Berdasarkan Tabel 3, dari 153 anak, terdapat 135 anak yang memiliki nilai skor-z BB/TB $\leq 2$ SD. Perilaku orang tua yang mengontrol perilaku makan anak signifikan berhubungan positif dengan status gizi 
Tabel 2. Gambaran skor perilaku orang tua dalam pemberian makan pada anak $(n=153)$

\begin{tabular}{|c|c|c|c|}
\hline Perilaku orang tua & Median & Q1 & Q3 \\
\hline Mengontrol perilaku makan anak & 3,2 & 2,8 & 3,5 \\
\hline $\begin{array}{l}\text { Menggunakan makanan untuk mengatur } \\
\text { emosi anak }\end{array}$ & 3,0 & 2,5 & 3,7 \\
\hline $\begin{array}{l}\text { Mendorong asupan makanan seimbang } \\
\text { dan bervariasi }\end{array}$ & 3,8 & 3,5 & 4,0 \\
\hline $\begin{array}{l}\text { Menyediakan lingkungan dengan } \\
\text { makanan sehat di rumah }\end{array}$ & 4,0 & 3,8 & 4,3 \\
\hline Menggunakan makanan sebagai hadiah & 3,0 & 2,3 & 3,7 \\
\hline $\begin{array}{l}\text { Melibatkan anak dalam perencanaan dan } \\
\text { persiapan makan }\end{array}$ & 2,7 & 2,0 & 3,3 \\
\hline Memantau asupan makanan & 3,5 & 3,0 & 4,0 \\
\hline Memberikan contoh makan yang sehat & 4,0 & 3,5 & 4,7 \\
\hline Memberikan tekanan saat makan & 3,5 & 3,0 & 4,3 \\
\hline $\begin{array}{l}\text { Pembatasan asupan makanan untuk } \\
\text { kesehatan }\end{array}$ & 3,3 & 2,8 & 3,8 \\
\hline $\begin{array}{l}\text { Pembatasan asupan makanan untuk } \\
\text { mengontrol berat badan }\end{array}$ & 1,9 & 1,4 & 2,5 \\
\hline Pengajaran tentang gizi & 3,7 & 3,3 & 4,3 \\
\hline
\end{tabular}

anak. Hal ini menunjukkan bahwa semakin bebas orang tua mengizinkan anak mengontrol perilaku makannya, status gizi anak semakin baik, sebaliknya semakin dikontrol ketat, status gizi anak semakin kurang. Perilaku menggunakan makanan sebagai hadiah dan memberikan tekanan berhubungan negatif dengan status gizi anak, orang tua yang tidak pernah menggunakan makanan untuk mengontrol emosi anak atau tidak pernah melakukan tekanan saat anak makan memiliki anak dengan status gizi baik/normal.

Tabel 4 menunjukkan bahwa dari 153 anak terdapat 147 anak yang memiliki nilai skor-z BB/TB $\geq$ -2 SD menunjukkan bahwa semakin sering orang tua membebaskan anak mengontrol perilaku makannya, memiliki anak yang gemuk. Memberikan tekanan saat makan berhubungan negatif dengan status gizi anak hal ini menunjukkan bahwa semakin jarang orang tua memberikan tekanan saat anak makan, memiliki anak yang gemuk. Pembatasan asupan makanan untuk mengontrol berat badan berhubungan positif dengan status gizi, orang tua yang selalu melakukan pembatasan asupan makanan untuk mengontrol berat badan memiliki anak yang gemuk. Sebaliknya, orang tua yang tidak pernah membatasi asupan makanan untuk mengontrol berat badan memiliki anak dengan status gizi normal.
Tabel 3. Hubungan skor perilaku orang tua dalam pemberian makan pada anak dengan skor-z $\mathrm{BB} / \mathrm{TB} \leq 2 \mathrm{SD}$, $\mathrm{n}=135$ (Spearman Correlation)

\begin{tabular}{|c|c|c|}
\hline \multirow[b]{2}{*}{$\begin{array}{l}\text { Perilaku orang tua dalam } \\
\text { pemberian makan pada anak }\end{array}$} & \multicolumn{2}{|c|}{ Status gizi anak } \\
\hline & $\begin{array}{c}\text { Koefisien } \\
\text { korelasi }(\rho)\end{array}$ & $\mathbf{p}$ \\
\hline $\begin{array}{l}\text { Mengontrol perilaku makan anak } \\
\text { (1=dikontrol ketat sampai } 5=\text { bebas) }\end{array}$ & 0,20 & $0,020 *$ \\
\hline $\begin{array}{l}\text { Menggunakan makanan untuk } \\
\text { mengatur emosi anak } \\
(1=\text { tidak pernah, sampai } 5=\text { selalu) }\end{array}$ & $-0,16$ & 0,060 \\
\hline $\begin{array}{l}\text { Mendorong asupan makanan seimbang } \\
\text { dan bervariasi } \\
(1=\text { tidak pernah, sampai } 5=\text { selalu })\end{array}$ & 0,12 & 0,200 \\
\hline $\begin{array}{l}\text { Menyediakan lingkungan dengan } \\
\text { makanan sehat di rumah } \\
(1=\text { tidak pernah, sampai } 5=\text { selalu) }\end{array}$ & 0,13 & 0,100 \\
\hline $\begin{array}{l}\text { Menggunakan makanan sebagai } \\
\text { hadiah } \\
(1=\text { tidak pernah, sampai } 5=\text { selalu })\end{array}$ & $-0,23$ & $0,007^{*}$ \\
\hline $\begin{array}{l}\text { Melibatkan anak dalam perencanaan } \\
\text { dan persiapan makan } \\
(1=\text { tidak pernah, sampai } 5=\text { selalu })\end{array}$ & 0,36 & $0,001^{*}$ \\
\hline $\begin{array}{l}\text { Memantau asupan makanan } \\
(1=\text { tidak pernah, sampai } 5=\text { selalu })\end{array}$ & 0,01 & 0,800 \\
\hline $\begin{array}{l}\text { Memberikan contoh makan yang } \\
\text { sehat } \\
(1=\text { tidak pernah, sampai } 5=\text { selalu })\end{array}$ & 0,20 & $0,010^{*}$ \\
\hline Memberikan tekanan saat makan & $-0,18$ & $0,030 *$ \\
\hline $\begin{array}{l}\text { Pembatasan asupan makanan untuk } \\
\text { kesehatan } \\
(1=\text { tidak pernah, sampai } 5=\text { selalu })\end{array}$ & 0,03 & 0,700 \\
\hline $\begin{array}{l}\text { Pembatasan asupan makanan untuk } \\
\text { mengontrol berat badan } \\
(1=\text { tidak pernah, sampai } 5=\text { selalu })\end{array}$ & 0,26 & $0,003^{*}$ \\
\hline $\begin{array}{l}\text { Pengajaran tentang gizi } \\
(1=\text { tidak pernah, sampai } 5=\text { selalu })\end{array}$ & 0,08 & 0,300 \\
\hline Total skor & $\mathbf{0 , 1 5}$ & $\mathbf{0 , 0 8 0}$ \\
\hline
\end{tabular}

* signifikan $(p<0,05)$

\section{BAHASAN}

Perilaku yang paling sering dilakukan orang tua adalah memberikan contoh makanan yang sehat. Lima tahun pertama kehidupan anak merupakan periode perilaku makan yang penting sebagai dasar pola makan yang akan datang. Dalam hal ini, peran orang tua sangat penting dalam pengalaman makan anak karena pengalaman ini akan berkaitan dengan perilaku makan anak dan status berat badan (18). Rerata skor orang tua dalam melakukan pembatasan untuk mengontrol berat badan sebesar 1,9 yaitu pada rentang tidak pernah sampai jarang. Hal ini disebabkan sebagian 
Tabel 4. Hubungan skor perilaku orang tua dalam pemberian makan pada anak dengan skor-z $\mathrm{BB} / \mathrm{TB} \geq \mathbf{- 2} \mathrm{SD}$, $\mathrm{n}=147$ (Spearman Correlation)

\begin{tabular}{|c|c|c|}
\hline \multirow{2}{*}{$\begin{array}{l}\text { Perilaku orang tua dalam } \\
\text { pemberian makan pada anak }\end{array}$} & \multicolumn{2}{|c|}{ Status Gizi anak } \\
\hline & $\begin{array}{l}\text { Koefisien } \\
\text { korelasi }(\rho)\end{array}$ & $\mathbf{p}$ \\
\hline $\begin{array}{l}\text { Mengontrol perilaku makan anak } \\
\text { (1=dikontrol ketat, sampai } 5=\text { bebas) }\end{array}$ & 0,21 & 0,010 \\
\hline $\begin{array}{l}\text { Menggunakan makanan untuk } \\
\text { mengatur emosi anak } \\
\text { (1=tidak pernah, sampai } 5=\text { selalu) }\end{array}$ & $-0,20$ & 0,020 \\
\hline $\begin{array}{l}\text { Mendorong asupan makanan seimbang } \\
\text { dan bervariasi } \\
(1=\text { tidak pernah, sampai } 5=\text { selalu) }\end{array}$ & 0,27 & 0,001 \\
\hline $\begin{array}{l}\text { Menyediakan lingkungan dengan } \\
\text { makanan sehat di rumah } \\
\text { (1=tidak pernah, sampai } 5=\text { selalu) }\end{array}$ & 0,22 & 0,008 \\
\hline $\begin{array}{l}\text { Menggunakan makanan sebagai } \\
\text { hadiah } \\
(1=\text { tidak pernah, sampai } 5=\text { selalu) }\end{array}$ & $-0,25$ & 0,002 \\
\hline $\begin{array}{l}\text { Melibatkan anak dalam perencanaan } \\
\text { dan persiapan makan } \\
(1=\text { tidak pernah, sampai } 5=\text { selalu })\end{array}$ & 0,43 & 0,001 \\
\hline $\begin{array}{l}\text { Memantau asupan makanan } \\
(1=\text { tidak pernah, sampai } 5=\text { selalu })\end{array}$ & 0,24 & 0,003 \\
\hline $\begin{array}{l}\text { Memberikan contoh makan yang } \\
\text { sehat } \\
(1=\text { tidak pernah, sampai } 5=\text { selalu) }\end{array}$ & 0,25 & 0,002 \\
\hline $\begin{array}{l}\text { Memberikan tekanan saat makan } \\
(1=\text { tidak pernah, sampai } 5=\text { selalu) }\end{array}$ & -0.34 & 0,001 \\
\hline $\begin{array}{l}\text { Pembatasan asupan makanan untuk } \\
\text { kesehatan } \\
(1=\text { tidak pernah, sampai } 5=\text { selalu) }\end{array}$ & 0,14 & 0,090 \\
\hline $\begin{array}{l}\text { Pembatasan asupan makanan untuk } \\
\text { mengontrol berat badan } \\
(1=\text { tidak pernah, sampai } 5=\text { selalu) }\end{array}$ & 0,29 & 0,001 \\
\hline $\begin{array}{l}\text { Pengajaran tentang gizi } \\
(1=\text { tidak pernah, sampai } 5=\text { selalu) }\end{array}$ & 0,18 & 0,030 \\
\hline Skor total & 0,24 & 0,003 \\
\hline
\end{tabular}

besar anak berada pada kondisi status gizi normal dan hanya $11,7 \%$ yang gemuk sehingga orang tua tidak melakukan pembatasan untuk mengontrol berat badan anak.

Perilaku orang tua dalam mengontrol perilaku makan anak berhubungan signifikan secara positif dengan status gizi anak usia 2-5 tahun pada kondisi anak kurus, normal maupun gemuk. Semakin sering orang tua membiarkan anak mengontrol pilihan dan asupan makan sendiri maka semakin tinggi status gizi anak. Kontrol makan anak merupakan praktik pemberian makan yang negatif karena orang tua membiarkan anak mengontrol sendiri pilihan dan asupan makanannya yang mempengaruhi seberapa banyak anak makan makanan yang sehat (19). Kemampuan mengontrol perilaku anak usia 2-5 tahun lebih berkembang sehingga anak memiliki kebebasan untuk memilih makanan yang diinginkan. Saat orang tua mengizinkan anak memilih dan makan makanan yang diinginkan maka anak memiliki kebebasan untuk memilih makanan yang disukai sehingga asupan makanan juga adekuat apabila didukung dengan berbagai pilihan makanan dengan zat gizi yang seimbang sesuai dengan kebutuhan anak. Kebebasan berlebihan dari orang tua juga dapat menyebabkan perilaku makan anak yang tidak sehat sehingga asupan makanan berlebihan dan tidak seimbang yang pada akhirnya anak menjadi gemuk.

Menggunakan makanan sebagai hadiah berhubungan signifikan secara negatif dengan status gizi anak pada status gizi anak sangat kurus hingga gemuk. Hal ini berarti bahwa semakin sering orang tua menggunakan makanan sebagai hadiah maka semakin rendah status gizi anak. Hasil temuan ini berbeda dengan penelitian sebelumnya bahwa body mass index (BMI) anak yang tinggi berhubungan dengan orang tua yang lebih sering menggunakan makanan sebagai hadiah (20). Hal ini dapat terjadi bahwa orang tua jarang menggunakan makanan sebagai hadiah berhubungan dengan status gizi anak yang gemuk. Orang tua yang menggunakan makanan sebagai hadiah atau tanda persetujuan dapat menyebabkan anak makan secara berlebihan, tetapi apabila makan dipaksakan maka makan menjadi saat yang tidak menyenangkan bagi anak (8). Dalam rangka menerima hadiah seperti makanan ringan atau bergula, anak dapat mengkonsumsi makanan yang lebih banyak daripada kebutuhannya karena makanan yang dijadikan sebagai hadiah lebih diinginkan sedangkan makanan yang sehat yang dibutuhkan menjadi kurang diinginkan sehingga mempengaruhi kualitas asupan makanan yang tidak sehat (21).

Melibatkan anak dalam perencanaan dan persiapan makan berhubungan secara positif dengan status gizi anak usia 2-5 tahun pada semua kondisi status gizi anak. Melibatkan anak dalam perencanaan makan dapat meningkatkan asupan makanan sehingga mempengaruhi status gizi, selain itu juga dapat menciptakan lingkungan makan yang dapat mempengaruhi kemampuan 
anak untuk makan. Dengan melibatkan anak dalam berbelanja atau merencanakan menu keluarga, anakanak diperbolehkan untuk membuat pilihan makanan mereka sendiri berdasarkan selera dan makanan yang diinginkan dengan menu seimbang sehingga asupannya juga sesuai dengan kebutuhan, tetapi apabila orang tua berlebihan dalam mengizinkan anak mengkonsumsi makanan yang diinginkan dari yang sudah direncanakan maka akan berhubungan dengan kejadian obesitas pada anak (22).

Hasil penelitian ini menunjukkan bahwa perilaku orang tua memberikan tekanan saat anak makan menunjukkan hubungan signifikan secara negatif dengan status gizi anak pada semua kondisi anak sangat kurus sampai gemuk. Hasil temuan ini sama dengan penelitian yang pernah dilakukan sebelumnya bahwa orang tua yang menggunakan lebih banyak tekanan untuk makan memiliki anak dengan indeks massa tubuh yang lebih rendah $(11,23,24)$. Penelitian longitudinal yang pernah dilakukan menunjukkan bahwa ketika berat badan anak tinggi maka orang tua menurunkan tekanan untuk makan pada anak (25). Orang tua yang memberikan tekanan untuk makan pada anak usia prasekolah dapat menyebabkan anak merasa kenyang lebih cepat sehingga asupan makanan menjadi lebih sedikit, selain itu konsumsi buah dan sayur menjadi lebih rendah (26).

Pembatasan asupan makanan untuk mengontrol berat badan berhubungan secara positif dengan status gizi anak usia 2-5 tahun pada semua kondisi status gizi anak sangat kurus sampai gemuk. Orang tua lebih banyak melakukan pembatasan untuk berat badan berhubungan dengan BMI yang tinggi $(11,18,20,27)$. Saat orang tua membatasi makanan tertentu, jika ada kesempatan untuk makan, anak akan makan lebih banyak (21). Perilaku pemberian makan kepada anak bukan hanya mempengaruhi status gizi anak dalam hal ini adalah berat badan anak, tetapi sebaliknya perilaku pemberian makan yang dilakukan oleh orang tua juga dipengaruhi oleh status gizi anak. Pada kondisi anak sangat kurus dan kurus, orang tua tidak pernah membatasi asupan makanan, tetapi pada kondisi anak yang gemuk, orang tua meningkatkan pembatasan untuk mengontrol berat badan anak. Hubungan secara kompleks mungkin tidak dapat dijelaskan dalam penelitian cross sectional ini.
Menyediakan lingkungan dengan makanan sehat di rumah berhubungan secara positif dengan status gizi anak usia 2-5 tahun pada kondisi anak dengan status gizi normal sampai gemuk. Pada kondisi ini dimungkinkan bahwa orang tua meningkatkan perilaku menyediakan lingkungan dengan makanan sehat di rumah sebagai respon karena kondisi anak yang gemuk. Hasil penelitian sebelumnya menyebutkan bahwa lingkungan makan yang disediakan orang tua bagi anak dapat mempengaruhi perkembangan perilaku makan yang sehat, asupan makanan, dan berat badan anak (28). Lingkungan positif yang mendorong anak untuk makan sangat penting bagi perkembangan fisik, mental, dan sosial (29). Lingkungan keluarga yang berkaitan dengan makan merupakan faktor yang sangat penting mempengaruhi perkembangan diet dan kebiasaan makan anak sehingga mempengaruhi asupan makanan (30). Orang tua yang menyediakan makanan yang sehat di rumah dapat membentuk perilaku makan yang sehat dan mempengaruhi perkembangan diet serta kebiasaan makan anak sehingga mempengaruhi asupan makanan $(22,31)$.

\section{SIMPULAN DAN SARAN}

Perilaku orang tua dalam pemberian makan pada anak berdasarkan comprehensive feeding practices questionnaire (CFPQ) berhubungan dengan status gizi anak kecuali perilaku membatasi asupan makanan untuk kesehatan. Orang tua diharapkan menghindari perilaku pemberian makan yang menggunakan makanan sebagai hadiah atau untuk mengatur emosi anak dan memberikan tekanan saat anak makan. Tenaga kesehatan yang ada di puskesmas diharapkan melakukan promosi kesehatan yang berkaitan dengan nutrisi dan perilaku orang tua dalam pemberian makan yang efektif dengan memberikan penyuluhan bagi ibu-ibu melalui kegiatan posyandu. Penelitian longitudinal selanjutnya dapat dilakukan untuk melihat hubungan sebab akibat perilaku orang tua dalam pemberian makan dan status gizi anak.

\section{RUJUKAN}

1. Orem DE, Taylor SG, Renpenning KM. Nursing concepts of practice. sixth. St. Louis: Mosby; 2001.

2. Lutter CK, Daelmans BMEG, de Onis M, Kothari MT, Ruel MT, Arimond M, Deitchler M, Dewey KG, Blössner 
M, Borghi E. Undernutrition, poor feeding practices, and low coverage of key nutrition interventions. Pediatrics 2011;128(6):e1418-27.

3. Kementerian Kesehatan RI. Buku saku asuhan gizi di puskesmas pedoman pelayanan gizi bagi petugas kesehatan. Yuwono S, Monarto, Irianto S, editors. Jakarta: Kementrian Kesehatan RI; 2012.

4. Badan Penelitian dan Pengembangan Kementerian Kesehatan RI. Riset kesehatan dasar (Riskesdas 2013). Jakarta: Kementerian Kesehatan RI; 2013.

5. WHO. Infant and young child feeding. Geneva: WHO Press; 2009.

6. Rodgers RF, Paxton SJ, Massey R, Campbell KJ, Wertheim $\mathrm{EH}$, Skouteris H, Gibbons K. Maternal feeding practices predict weight gain and obesogenic eating behaviors in young children: a prospective study. Int J Behav Nutr Phys Act 2013;10:24.

7. Murashima M, Hoerr SL, Hughes SO, Kattelmann KK, Phillips BW. Maternal parenting behaviors during childhood relate to weight status and fruit and vegetable intake of college students. J Nutr Educ Behav 2012;44(6):556-63.

8. Hockenberry MJ, Wilson D. Wong's nursing care of infants and children, 9e. St. Louis: Mosby; 2011.

9. Kolopaking R, Bardosono S, Fahmida U. Maternal selfefficacy in the home food environment: a qualitative study among low-income mothers of nutritionally at-risk children in an urban area of Jakarta, Indonesia. J Nutr Educ Behav 2011;43(3):180-8.

10. Chaidez V, Townsend M, Kaiser LL. Toddler-feeding practices among Mexican American mothers. A qualitative study. Appetite 2011;56(3):629-32.

11. Jansen PW, Roza SJ, Jaddoe VW, Mackenbach JD, Raat H, Hofman A, et al. Children's eating behavior, feeding practices of parents and weight problems in early childhood: results from the population-based Generation R Study. Int J Behav Nutr Phys Act 2012;9(1):130.

12. Ernawati A. Hubungan Faktor sosial ekonomi, higiene sanitasi lingkungan, tingkat konsumsi dan infeksi dengan status gizi anak usia 2-5 tahun di Kabupaten Semarang [Tesis]. Semarang: Magister Gizi Masyarakat Program Pascasarjana Universitas Diponegoro; 2006.

13. Santi DY, Utama SP, Putranto AMH. Hubungan antara kondisi sosial ekonomi dan higiene sanitasi lingkungan dengan status gizi anak usia 2-5 tahun di Kecamatan Seginim Kabupaten Bengkulu Selatan. Naturalis 2012;1(2):141-6.

14. Risma. Hubungan antara status pekerjaan ibu dengan status gizi dan perkembangan anak usia 1-3 tahun di Kecamatan Kadia Kota Kendar [Tesis]. Yogyakarta: Program Studi Ilmu Kesehatan Masyarakat, Program Pasca Sarjana Fakultas Kedokteran Universitas Gadjah Mada; 2009.
15. Musher-Eizenman D, Holub S. Comprehensive feeding practices questionnaire: validation of a new measure of parental feeding practices. J Pediatr Psychol 2007;32(8):960-72.

16. Blissett J, Haycraft E, Farrow C. Inducing preschool children' s emotional eating: relations with parental. Am J Clin Nutr 2010;92:359-65.

17. Gubernur Jawa Timur. Peraturan Gubernur Jawa Timur Nomor 78 tentang Upah Minimum Kabupaten/Kota di Jawa Timur tahun 2014. Surabaya: Gubernur Jawa Timur; 2013.

18. Savage JS, Fisher JO, Birch LL. Parental influence on eating behavior. J Law Med Ethics 2008;35(1):22-34.

19. Kiefner-Burmeister AE, Hoffmann DA, Meers MR, Koball AM, Musher-eizenman DR. Food consumption by young children: a function of parental feeding goals and practices. Appetite 2014;74:6-11.

20. Musher-Eizenman DR, de Lauzon-Guillain B, Holub SC, Leporc E, Charles MA. Child and parent characteristics related to parental feeding practices. a cross-cultural examination in the US and France. Appetite 2009;52(1):8995.

21. Forthun L. Family Nutrition: parenting and family life 1. Gainesville, Florida: The Institute of Food and Agricultural Sciences (IFAS); 2012.

22. Boucher N. Feeding styles and the body weight status of preschool-aged children. TJNP J Nurse Pract 2014;10(4):234-9.

23. Tschann JM, Gregorich SE, Penilla C, Pasch LA, de Groat CL, Flores E, Deardorff J, Greenspan LC, Butte NF. Parental feeding practices in Mexican American families: initial test of an expanded measure. Int J Behav Nutr Phys Act 2013;10:6.

24. Blissett J, Meyer C, Haycraft E. Maternal and paternal controlling feeding practices with male and female children. Appetite 2006;47(2):212-9.

25. Webber L, Cooke L, Hill C, Wardle J. Child adiposity and maternal feeding practices: a longitudinal analysis $1-3$. Am J Clin Nutr 2010;92:1423-8.

26. Gregory JE, Paxton SJ, Brozovic AM. Maternal feeding practices predict fruit and vegetable consumption in young children. Results of a 12-month longitudinal study. Appetite 2011;57(1):167-72.

27. Sud S, Tamayo NC, Faith MS, Keller KL. Increased restrictive feeding practices are associated with reduced energy density in 4-6-year-old, multi-ethnic children at ad libitum laboratory test-meals. Appetite 2010;55(2):201-7.

28. Scaglioni S, Salvioni M, Galimberti C. Influence of parental attitudes in the development of children eating behaviour. Br J Nutr 2008;99 Suppl 1:S22-5. 
29. Moore AC,Akhter S,Aboud FE. Responsive complementary feeding in rural Bangladesh. Soc Sci Med 2006;62(8):191730 .

30. Hendrie G, Sohonpal G, Lange K, Golley R. Change in the family food environment is associated with positive dietary change in children. Int J Behav Nutr Phys Act 2013;10(1):1.

31. Loth AKA, Maclehose RF. Food-related parenting practices and adolescent weight status: a population-based study. Pediatrics 2013;131(5):1443-50. 